\title{
In-Vitro Evaluation of the Nematicidal Potential of Leaf Extracts of Commenlina benghalensis and Bidens pilosa on Root-Knot Nematode (Meloidogyne Spp)
}

\author{
Okechalu, Ode Brains* Oyeyinka, Jeremiah Danahap, L. Sambo \\ Department of Plant Science and Biotechnology, University of Jos, PMB 2084, Jos, Plateau State, Nigeria
}

\begin{abstract}
The nematicidal potential of leaf extracts of Commenlina benghalensis and Bidens pilosa on Root-knot nematodes (Meloidogyne spp) was evaluated in-vitro. Four concentrations of the aqueous extracts of the leaves of each plant was used for the test. The concentration included $100 \mathrm{mg} / \mathrm{ml}, 150 \mathrm{mg} / \mathrm{ml} \mathrm{200mg/ml} \mathrm{and} 250 \mathrm{mg} / \mathrm{ml} \mathrm{while} \mathrm{distilled}$ water was used as control. Root-knot nematodes were sourced from susceptible plants within Jos metropolis and challenged with the different concentration of the extracts. Observation was done 24 hourly for 96 hours. Also, phytochemical analysis of the extracts was done. The results showed that all the extracts had nematicidal activities on root-knot nematodes but to varying degrees. Generally, $C$. benghalensis had lower nematicidal activity than $B$. pilosa. The result also showed that the nematicidal activities of both plant extracts increased with concentration and time of exposure. The phytochemical screening showed the presence of bioactive compounds such as Alkaloid, Saponin, Tannin, and Flavonoid among others. The findings of this work suggests that these plants have good nematicidal potentials.
\end{abstract}

Keywords: Root-knot nematodes, in-vitro, Commenlina benghalensis, Bidens pilosa

DOI: $10.7176 / \mathrm{JNSR} / 10-4-04$

Publication date: February $29^{\text {th }} 2020$

\section{Introduction}

LaMondia (2004) reported that nematodes are some of the most numerous multi-cellular animals on earth. They exist in a vast array of ecologic relationships and may be found in almost every kind of ecologic niche available, from the arctic to deserts or the depths of the oceans. A handful of soil may contain many thousands of these microscopic worms.

Most nematodes are simple, colorless and translucent roundworms with relatively little morphological divergence. Nematodes have no appendages and are barely visible to the naked eye, but are, however, easily observed under a microscope (Agrios, 2005). Although, nematodes are generally wormlike in shape, mature females of some genera, namely Meloidogyne, Heterodera, and Nacobbus have swollen, saccate-like bodies (Agrios, 2005).

Nematodes belong to the animal kingdom Animalia and comprise a large phylum (Nematoda) that includes plant, animal, human and free-living species. Parasitism of plants by nematodes is restricted to two classes, namely the Adenophora and Secernentea. Adenophorean parasites are confined to the two families Longidoridae and Trichodoridae within the order Dorylaimida (Perry et al., 2009). Plant-parasitic nematodes are obligate, bio trophic organisms that obtain nutrients only from the cytoplasm of living plant cells (Agrios, 1997). The stylet distinguishes plant-parasitic nematodes from free-living nematodes (Luc, et al, 2005).

Plant parasitic nematode is one of the major factors causing unbearable and uncontrollable biotic stress in plants. They are however, rarely detected due to their subterranean habit, microscopic size (from 0.3 to $10 \mathrm{~mm}$ Length) and ability to mimic other stress factors such as nutrient deficiency (Torr et al., 2007). They have been reported to Cause as much as $\$ 125$ billion in annual losses of economic crops worldwide (Chitwood, 2003). In the tropics and subtropics, the crop losses due to nematodes is $14.6 \%$ compared to $8.8 \%$ in temperate regions (Nicol, et al., 2011)

Plant parasitic nematodes are composed of several genera. Of the many genera so far described, ten have been found to be of economic importance in Agriculture with Meloidogyne spp. (root-knot nematodes) on top of the list (Jones et al., 2013). There are over 90 characterized species of economic importance in the Meloidogyne spp group which are obligate endoparasites that are capable of infecting nearly every species of higher plants in a wide range of geographical distribution ( Favery, et al., 2016). The estimated global yield losses for arable crops associated with RKNs are estimated between 5-43\% in the tropical and subtropical areas. In the tropics M. incognita, M. javanica, M. arenaria are the most dominant species (Perry, et al., 2009).

Plant parasitic nematodes cause damage by establishing a parasitic relationship with their host plants thereby transforming vascular cells into giant or multinucleate feeding from which they exploit nutrients and water (Gheysen and Mitchum, 2011) Plants infected with root-knot nematodes may show slow or stunted growth. Infections may also occur without causing any above-ground symptoms, the typical damage caused through feeding by root-knot nematode are different sized galls formed on the plant roots (Budai et al., 2005) or knots on 
roots from where the nematodes derive their name. The symptoms of nematode infection may vary among crops in field, they occur as oval patches or elongated patches, root galling, stunting, leaf shows lesions, chlorosis (yellowing), premature wilting, malformed fruit and overall reduction in growth of plants. They penetrate and feed on the root of growing plants, stealing nutrients vital for plant growth and exposing the roots to overall reduction in growth of plants. They penetrate and feed on the root of growing plants, stealing nutrients vital for plant growth and exposing the roots to attack by other soil pathogen. The infection of plants by these nematodes can also be visualized as stunted growth, wilting and susceptibility to various other pathogens (Williamson and Hussey, 1996).

Root-knot nematodes are capable of infecting over 2000 host plants including all major field crops, vegetables, ornamental plants, fruit trees and some weed species with ability of compatible interaction of up 8 weeks in the roots (Dubreuil, et al., 2011). The host range of root-knot nematodes is so vast that it is difficult to find a common landscape and garden as non-hosts while it has been found that vegetables bedding plants, shrubs as well as trees are all susceptible hosts (Olsen, 2000).

A number of nematode control measures abound. Chemical control is one of the oldest methods of controlling nematodes. Nematicides are chemicals used in the field of agriculture to mitigate the negative effects of plant parasitic nematodes on plant health and subsequently on crop productivity and/or quality. Chemicals such as carbofuran, carbosulfan, and fenamiphos have been tried in controlling $M$. incognita and have shown good results in the treatment of seeds when dressed and soil fumigation (Khan, 2004).

Cultural controls are one of the broadest method for management of RKNs and involves cropping systems, fallowing, solarization, use of organic amendments, intercropping, age of transplantable nurseries, altering dates of planting, removal of infected plants and burning of crop residues (Khan, et al., 2014).

Biological control of plant parasitic nematodes is achieved by use of antagonistic organisms, conservation of local antagonistic or combination of the two in soil by either naturally occurring or introduction techniques (Sikora, 1992).

Antagonistic plants are those that are considered to produce toxic substances to target organisms when the crop is growing or after its incorporation into the soil (Kayani, et al., 2012). This strategy is used in nematode management and its approach relies mainly on pre plant cover crops, green manuring or intercropping. Marigold, neem, sun hemp, partridge pea, asparagus among other have been studied and used as antagonistic plants for nematode management (Adekunle, 2011)

\subsection{COMMELINA BENGHANLENSIS}

Commelina benghalensis Linn. belongs to the family Commelinaceae and is a perennial native herb found in most parts of tropical Asia and Africa. The plant is commonly known as Benghal dayflower or dew flower. It is large, meander, herbs that grows to a height of about $40 \mathrm{~cm}$ long and have roots with basal nodes. The plant can be characterized by its attractive and little bluish-violet flowers. Commelina benghalensis can be an annual or perennial herb. Leaves are ovate to lancolate, $2.5-7.5 \mathrm{~cm}$ long, $1.5-4 \mathrm{~cm}$ wide, with parallel venation, entire leaf margins, and pubescence on top and bottom. (Webster et al., 2005).

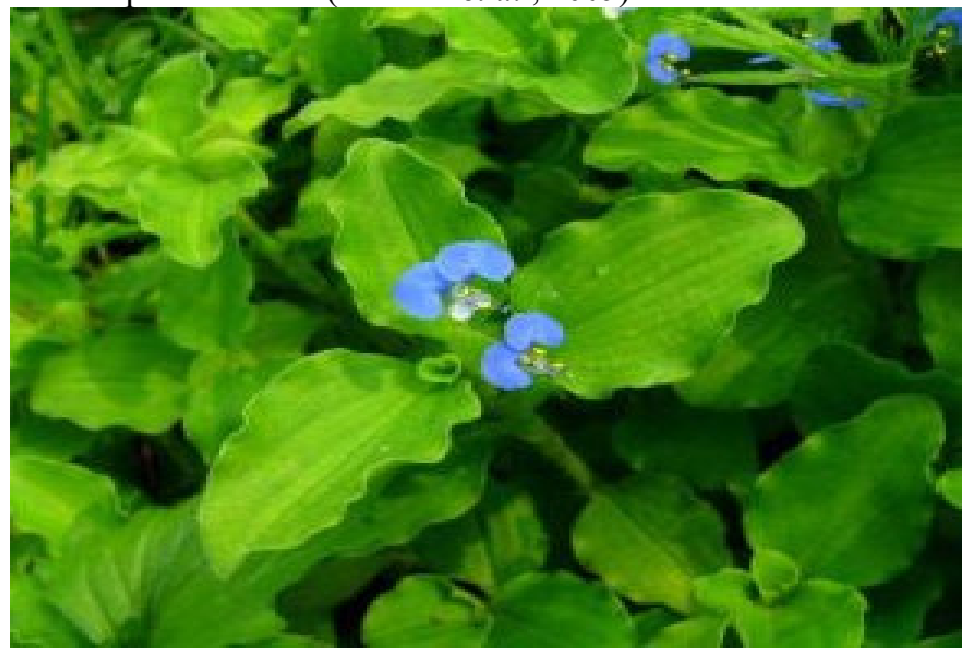

Plate 1: photograph of Commenlina benghalensis

\subsection{BIDENS PILOSA}

Bidens pilosa is a species of flowering plant in the aster family. It is native to the Americas but it is known widely as an introduced species of other regions, including Eurasia, Africa, Australia, and the Pacific Islands. It is a tall branched weed with thin yellow flowers that develop into a cluster of barbed fruits. Its many common names include black-jack, beggar-ticks, cobbler's pegs, farmer's friends and Spanish needle. Bidens pilosa is an annual 
herb with an erect habit to $1.5 \mathrm{~m}$ in height It is easily recognised by the enlongated fruits that bear hooked bristles (burrs) that embed themselves in people's clothing as they brush past the stems (Manandhar. 2000).

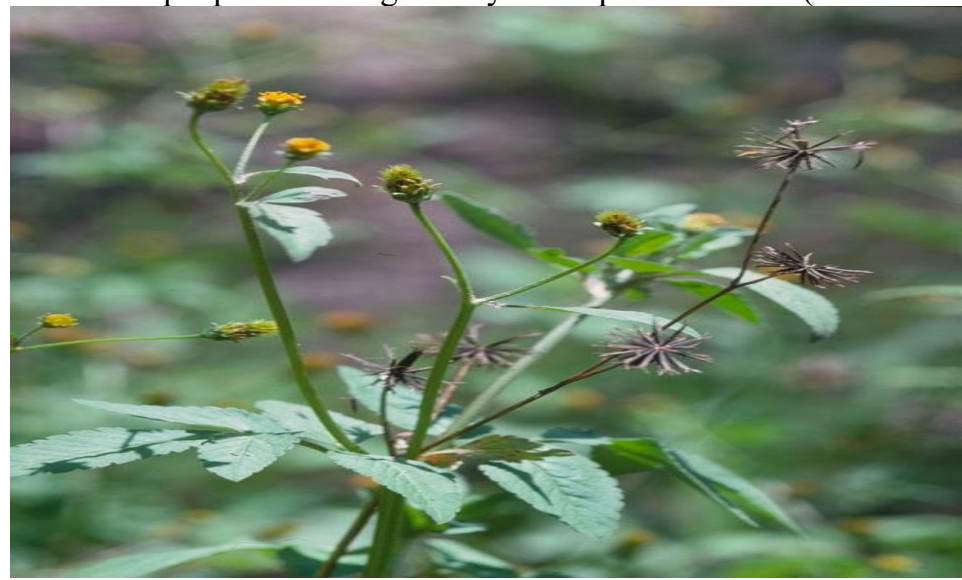

PLATE 2: Photograph of Bidens pilosa

\subsection{Statement of the Problem}

Root-knot nematode (Meloidogyne spp) are important economic pests of many cultivated crops and currently chemical nemacidies used for control are being phased out due to their high cost and toxicity (Lamovsek et al., 2013). Root-knot nematode reduces yield and quality of agricultural products consequently causing economic losses to the agricultural industry. Globally it has been reported that Root-knot nematode has cause as high as \$157billion dollar loss annually (Singh, et al., 2015). Chemical control using nematicides is slowly becoming extinct from the global market due to their toxicity and effect on human, livestock and environment hence the need to invest in safer eco-friendly practices for management of Root knot nematode (Collange et al., 2011). Concerns are growing over chemical pesticides in respect to ground water contamination residue on food and development of resistance by pest has prompted for safer means of control such as biological control (Hussaini, 2014). This, therefore forms the background for this study with the aim to evaluate the nematicidal potential of leaf extracts of Commenlina benghalensis and Bidens pilosa on Root-knot nematodes in-vitro. The specific objectives were to: determined the nematicidal activities of four different concentrations $(100 \mathrm{mg} / \mathrm{ml}, 150 \mathrm{mg} / \mathrm{ml}$, $200 \mathrm{mg} / \mathrm{ml}$ and $250 \mathrm{mg} / \mathrm{ml}$ ) of leaf extracts of Commenlina benghalensis and Bidens pilosa leaf extracts on Root- knot nematodes in the laboratory.

ii. determined effect of time of exposure on the nematicidal activities of the extracts.

iii. identify the possible chemical constituents of Commenlina benghalensis and Bidens pilosa.

\section{Materials and Method}

\subsection{Extraction of Nematodes}

The Root-knot Nematodes were extracted from the roots and rhizospheres of suspected host (particularly tomato and banana) cultivated in Jos North LGA and its environs. The host plants roots were carefully excised and then teased with the aid of teasing pins and forceps to expose and release the nematodes from the root tissue. The extraction of root-knot nematode from the host plant root was done using the modified Baermann Funnel method (Southey, 1970). Baermann funnel is a regular laboratory funnel with a piece of rubber tube about $25-30 \mathrm{~cm}$ long attached to the stem of the funnel. The tube is in turn connected to a test tube tightly held together with the aid of masking tape. The set up was kept in an upright position using a table stand with small regular holes and was filled with distilled water to the brim of the funnel's stem. Cotton wool was place in the funnel to assume the shape of the funnel so that the water slightly covered the wool before the teased root samples for extraction of nematodes were placed on the cotton wool and covered with water to prevent the sample from drying. The set up was allowed to stand for 24 hours. The nematode juveniles been active readily passed through the cotton wool down the funnel stem and were collected at the bottom of the test tube. Fifteen set of the techniques were used so as to obtain enough quantity of the inoculum. The test tubes were then carefully removed and its content centrifuged at 2000 RPM (Revolution per minute) for 5 minute to concentrate the nematode juveniles at the bottom of the test tubes.

\subsection{Estimation of Nematode Population}

Nematode populations were estimated by counting the number of active juveniles in $1 \mathrm{ml}$ of homogenized suspension of Root-Knot nematodes under a binocular research light microscope at X40 magnification. $1 \mathrm{ml}$ of homogenized suspension contained an average of 20 nematode juvenile. 


\subsection{Preparation of Leaf Extracts of Test Plants}

The Commenlina benghalensis and Bidens pilosa leaf extracts were prepared from freshly harvested leaves of both plants, each plant leaves were room dried to a constant weight then they were pulverized using mortar and pestle.

The powdery form of the each pulverized leaf was weigh to $100 \mathrm{~g}$ each and soaked in $1000 \mathrm{ml}$ of distilled water and left to stand for 72 hours (3days) then it was filtered using a white muslin cloth. The filtered liquid solution of plant was then evaporated using hot plate at a temperature of $50^{\circ} \mathrm{C}$. The resultant powdered extract was collected and used for the nematicidal test. Different concentrations of the Commenlina benghalensis and Bidens pilosa were then prepared by dissolving variable quantities of the extracts in distilled water to give the following concentrations: $250 \mathrm{mg} / \mathrm{ml}, 200 \mathrm{mg} / \mathrm{ml}, 150 \mathrm{mg} / \mathrm{ml}, 100 \mathrm{mg} / \mathrm{ml}$

\subsection{The Nematicidal Test}

The nematicidal test was conducted in-vitro using freshly prepared leaf extracts of Commenlina benghalensis and Bidens pilosa and freshly extracted nematodes. The extraction of nematodes and preparation of the fresh extracts were done concurrently to ensure the use of fresh extracts and very active second stage larvae (juvenile). $1 \mathrm{ml}$ of each concentration of extract was added to $5 \mathrm{mls}$ of homogenized suspension of root-knot nematode suspension, this was replicated three times for each concentration and examined at 24, 48, 72 and 96 hours for live and immobilized nematodes. The experiment was laid out in a Randomized Complete Block Design with 2 plant extracts, 4 concentrations for each extract, a control (Nematode suspension + distilled water without extract) and 3 replicates for each treatment.

The number of immobilized nematodes were counted and expressed as percentage of mortality and recorded. The immobile nematodes were then transferred to distilled water after 96 hours to ascertain whether or not they regain mobility. The nematode suspension to which no extract was added served as control.

\subsection{Phytochemical Analysis}

The phytochemical analysis for qualitative detection of flavonoids, tannins, alkaloids, saponins, phlobatannin, cardiac glycosides, steroids, terpenoids and anthraquinone were performed on the plant extracts of both plants as described by AOAC (2007).

\subsection{Statistical Analysis}

The data generated were analyzed statistically using two-way analysis of variance (ANOVA) and means were separated using the Least Significance Difference (LSD).

\section{Results}

The study revealed that the leaf extracts of $C$. benghalensis and B. pilosa had nematicidal activities on root-knot nematodes but to varying degrees. The result also showed that the nematicidal activities increased with increase in concentration and time of exposure (Table 1). The concentration $250 \mathrm{mg} / \mathrm{ml}$ showed the highest nematicidal activity while $100 \mathrm{mg} / \mathrm{ml}$ had the least. The highest mortality was recorded at 96 hours of exposure while the least was at 24 hours of exposure for both plant extracts (Table 1). Mortality was recorded for the control treatment too; it was however less than those of the different leaf extracts.

The estimated mean number of the live nematodes decreased with increasing concentration of extracts across the time of exposure. At 24 Hours of exposure, the distilled water had the highest number of live nematodes while $250 \mathrm{mg} / \mathrm{ml}$ had the least. (Figure 1). At 48 hours of exposure, B. pilosa generally had the least number of live nematode across concentration except at $250 \mathrm{mg} / \mathrm{ml}$ where both $B$. pilosa and $C$. benghalensis had the same number of live nematodes. (Figure 2). At 18 hours of exposure, B. pilosa had the least number of live nematodes at concentration $150 \mathrm{mg} / \mathrm{ml}$ and $250 \mathrm{mg} / \mathrm{ml}$ but the number of live nematodes were the same for both extracts at concentration $100 \mathrm{mg} / \mathrm{ml}$ and $250 \mathrm{mg} / \mathrm{ml}$ (Figure 3). Figure 4 revealed that B. pilosa had the least number of live nematode after 96 hours.

Percentage mortality was generally higher for B. pilosa leaf extract as compared to C. benghalensis leaf extract. The highest percentage mortality was recorded at $250 \mathrm{mg} / \mathrm{ml}$ after 96 hours i.e $83.33 \%$ (B. pilosa) and $80.00 \%$ (C. benghalensis) (Table 2).

Statistical analysis revealed that the nematicidal activities of the two plant extracts were significantly higher $(p<0.05)$ than that of the control. However, the plant extracts did not differ from each other in their nematicidal activity.

The phytochemical screening revealed the presence of bioactive compounds such as Alkanoid, Saponin, Tannin, Flavonoid among others (Table 3) 
Table 1: Estimated Mean Mortality of Nematode Exposed To Different Concentration of Leaf Extracts of C. benghalensis And B. pilosa At Different Time Interval.

\begin{tabular}{lllllll}
\hline Plant extract & concentration & 24 hours & 48 hours & 72 hours & 96 hours & LSD \\
\hline C. benghalensis & $250 \mathrm{mg} / \mathrm{ml}$ & 12.67 & 13 & 14.67 & 16 & 0.56 \\
C. benghalensis & $200 \mathrm{mg} / \mathrm{ml}$ & 11 & 11.33 & 9 & 13.67 & \\
C. benghalensis & $150 \mathrm{mg} / \mathrm{ml}$ & 9.33 & 9 & 7 & 11.33 & \\
C. benghalensis & $100 \mathrm{mg} / \mathrm{ml}$ & 6.33 & 7 & 5.67 & 10 & \\
B. pilosa & $250 \mathrm{mg} / \mathrm{ml}$ & 12 & 13 & 14.67 & 16.67 & \\
B. pilosa & $200 \mathrm{mg} / \mathrm{ml}$ & 10.67 & 12.33 & 13 & 13.67 & \\
B. pilosa & $150 \mathrm{mg} / \mathrm{ml}$ & 9.33 & 11.33 & 11 & 13 & \\
B. pilosa & $100 \mathrm{mg} / \mathrm{ml}$ & 6.33 & 7 & 8 & 7.67 & \\
Control & Distilled & 1.67 & 0.33 & 1.33 & 1 & \\
& Water & & & & & \\
& LSD & 0.59 & & & & \\
& &
\end{tabular}

Table 2; Mean Percentage Mortality Number of Nematode Juvenile Per 1 mil Of Nematode Suspension Exposed to Varying Concentration of Leaf Extract of Commenlina benghalensis And Bidens pilosa At Different Time Interval

\begin{tabular}{lllllll}
\hline \multicolumn{1}{c}{ Plant extract } & concentration & 6hour & 12hour & 18hour & 24hour & LSD \\
\hline C. benghalensis & $250 \mathrm{mg} / \mathrm{ml}$ & 63.33 & 65.00 & 73.33 & 80.00 & 0.56 \\
C. benghalensis & $200 \mathrm{mg} / \mathrm{ml}$ & 55.00 & 56.66 & 45.00 & 68.33 & \\
C. benghalensis & $150 \mathrm{mg} / \mathrm{ml}$ & 46.66 & 45.00 & 35.00 & 56.66 & \\
C. benghalensis & $100 \mathrm{mg} / \mathrm{ml}$ & 31.66 & 35.00 & 28.33 & 50.00 & \\
B. pilosa & $250 \mathrm{mg} / \mathrm{ml}$ & 60.00 & 65.00 & 73.00 & 83.33 & \\
B. pilosa & $200 \mathrm{mg} / \mathrm{ml}$ & 53.33 & 61.66 & 65.00 & 68.33 & \\
B. pilosa & $150 \mathrm{mg} / \mathrm{ml}$ & 46.66 & 56.66 & 55.00 & 65.00 & \\
B. pilosa & $100 \mathrm{mg} / \mathrm{ml}$ & 31.66 & 35.00 & 40.00 & 38.33 & \\
Control & Distilled & 8.33 & 1.67 & 6.67 & 5.00 & \\
& Water & & & & & \\
& LSD & 0.40 & & & & \\
\hline
\end{tabular}

Table 3 Phytochemical Constituents of Leaf Extract of C. benghalensis And B. pilosa

\begin{tabular}{lcc}
\hline Chemical & present/absent & present/absent \\
Constituent & C. benghalensis & B. pilosa \\
\hline Alkaloid & + & - \\
Saponin & + & + \\
Cardiac glycoside & + & + \\
Tannin & + & + \\
Steroid & - & + \\
Flavonoid & + & + \\
Phlobattam & + & + \\
Anthraqunioes & + & +
\end{tabular}

KEY: + = present

$$
\text { - = absent }
$$




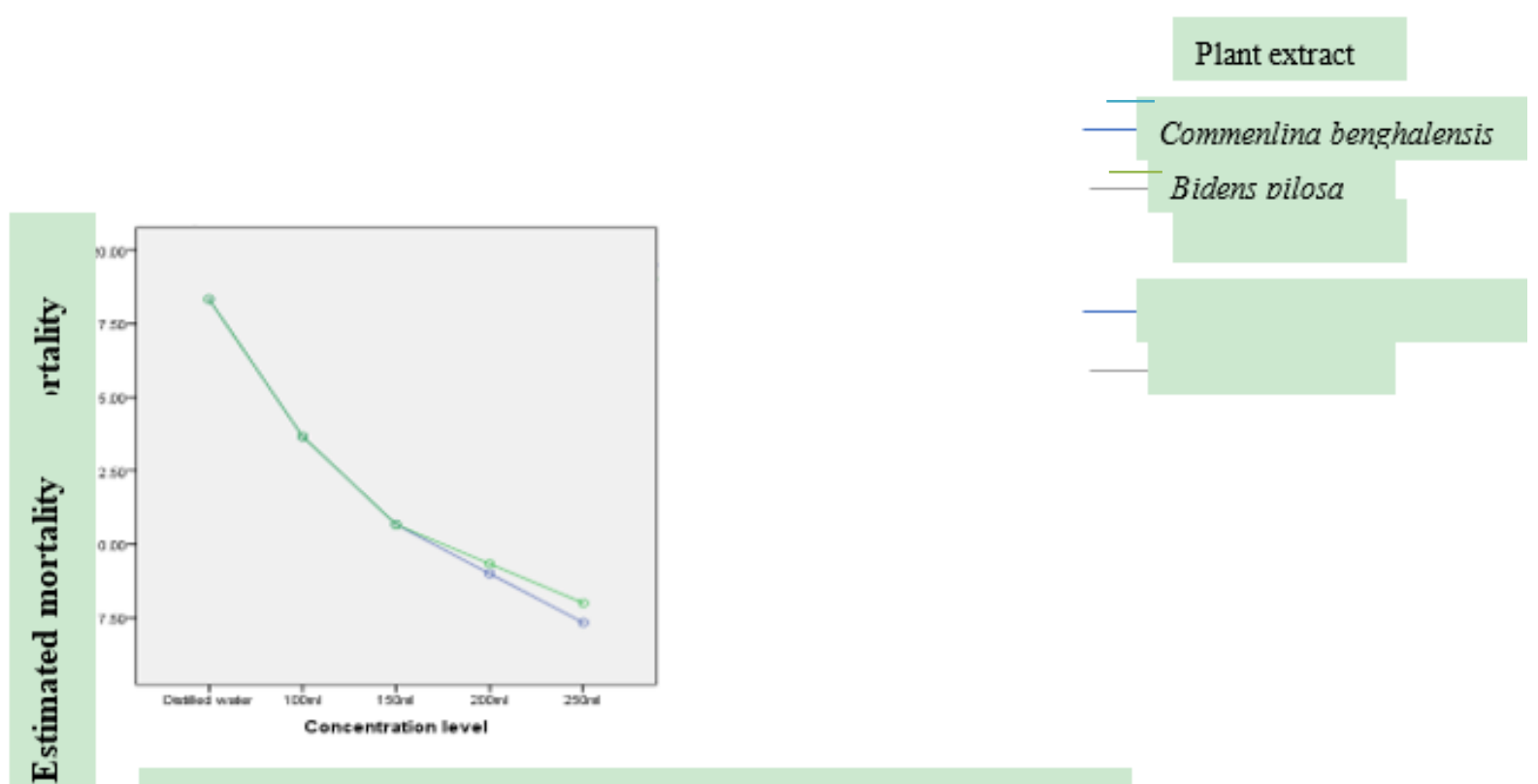

Fig 1: Estimated Mean Number of Live Nematode at 24 Hours of Exposure To Varying Concentration Of Test Plants

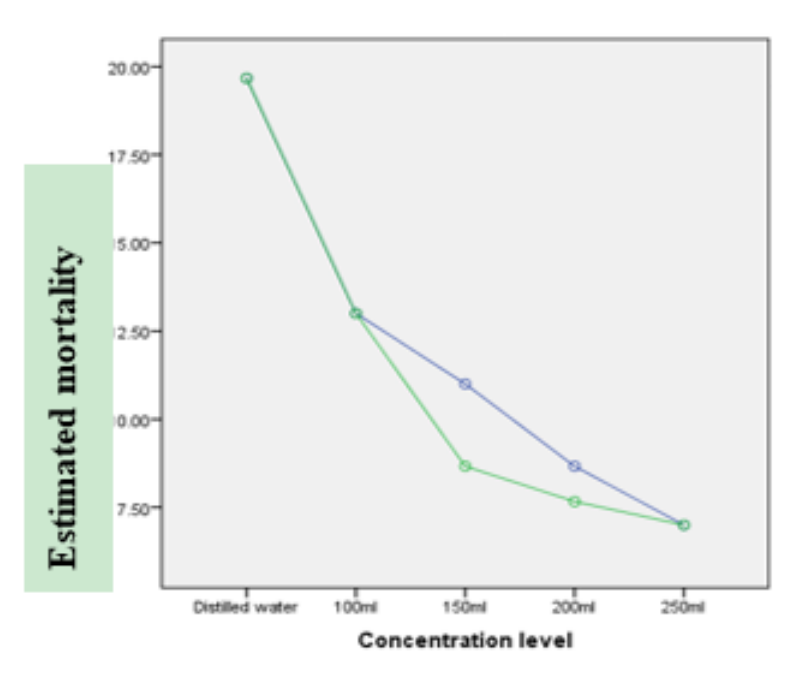

Plant extract

Fig 2: Estimated Mean Number of Live Nematode at 48 Hours of Exposure To Varying Concentration Of Test Plants 


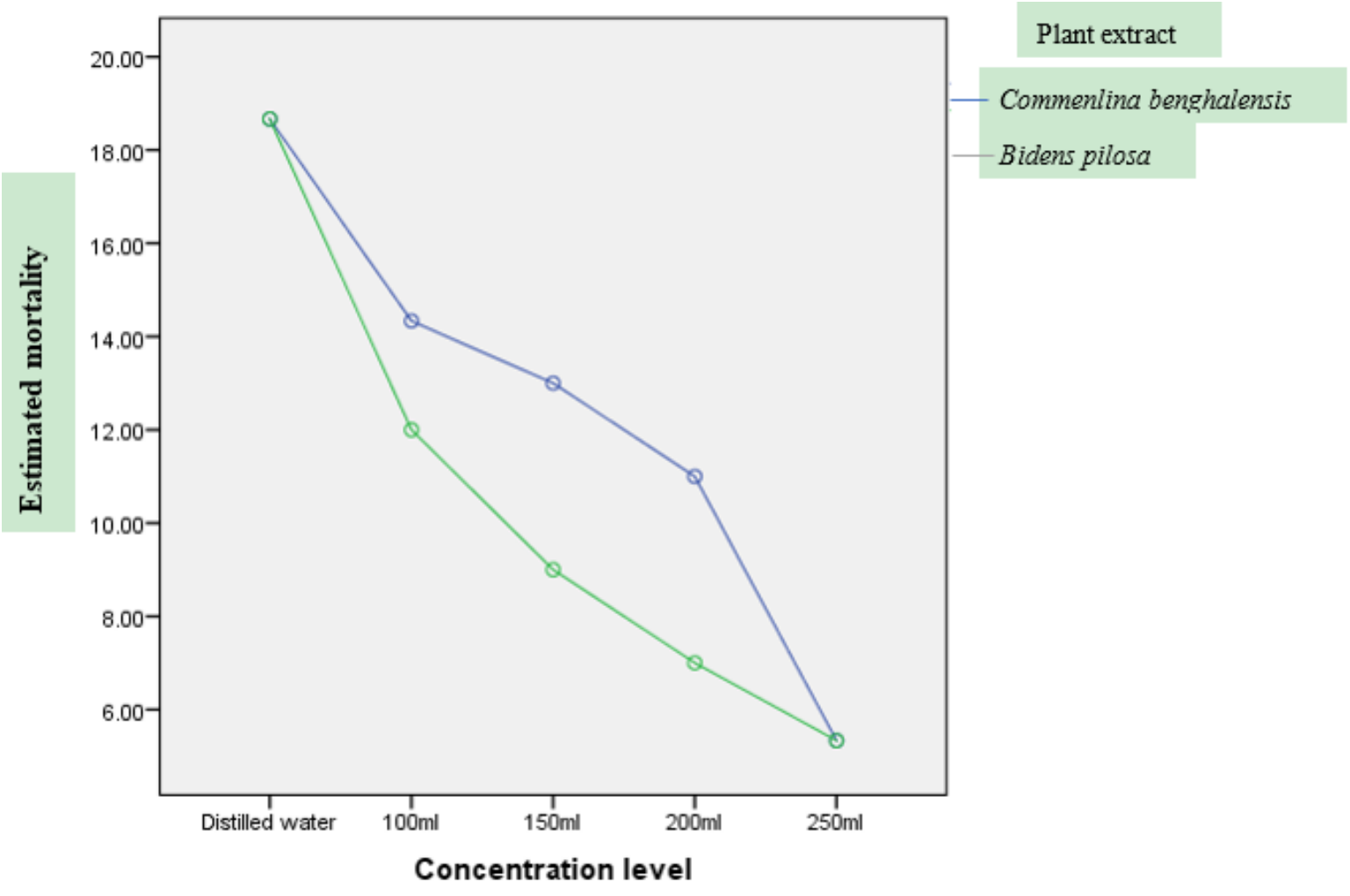

Fig 3: Estimated Mean Number of Live Nematode at 72 Hours of Exposure To Varying Concentration Of Test Plants

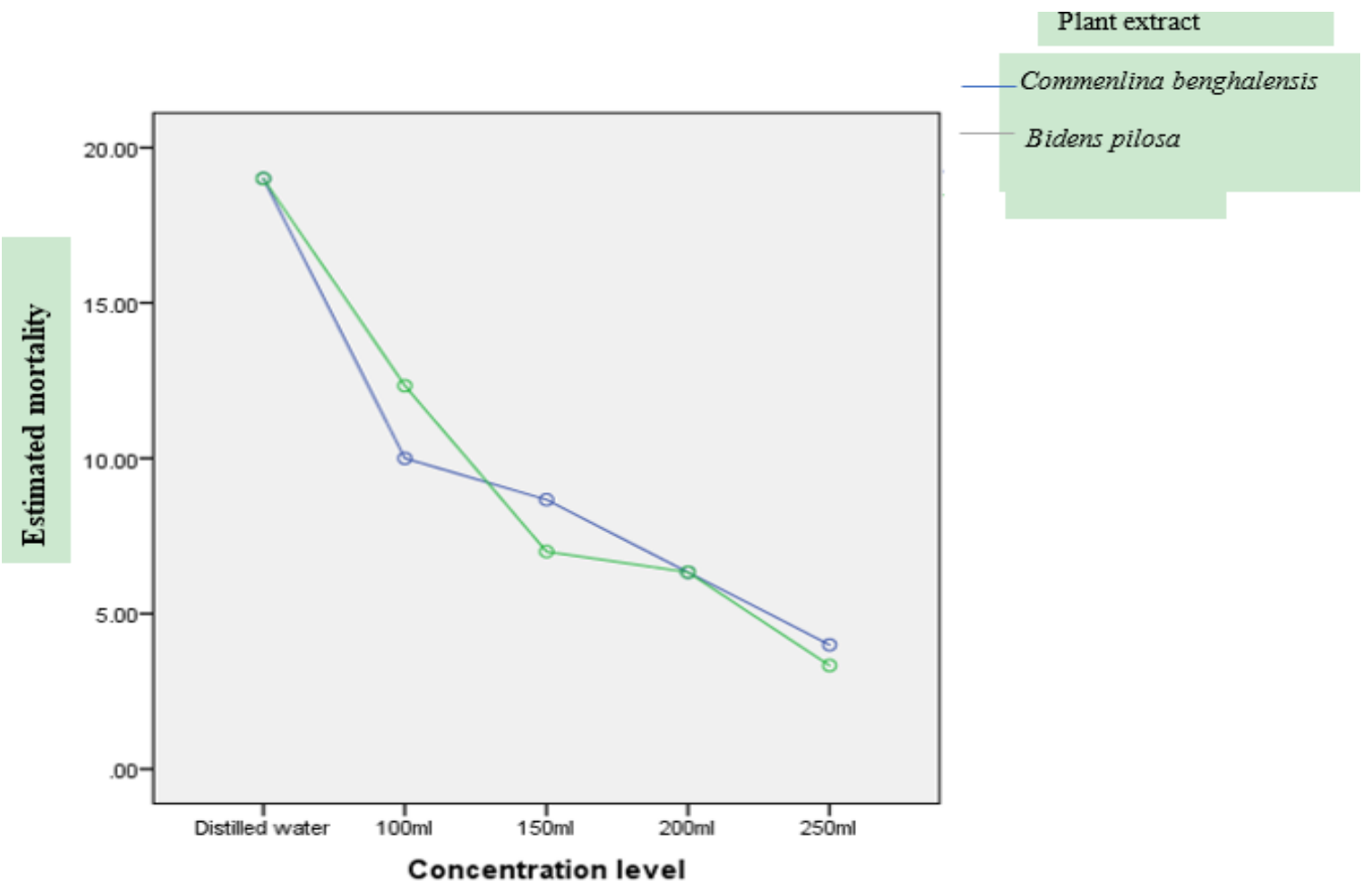

Fig 4: Estimated Mean Number of Live Nematode at 96 hrs of Exposure To Varying Concentration Of Test Plants 


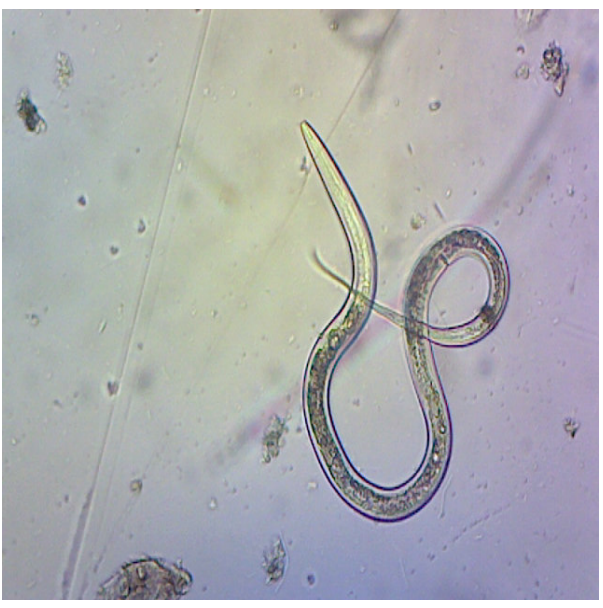

Plate 3: Photomicrograph of Nematode Juvenile Before Treatment with Plant Extracts

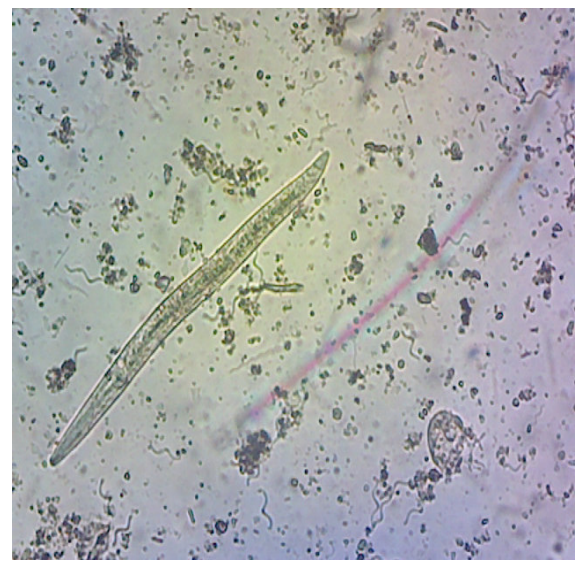

Plate 5: Photomicrograph of Nematode Juvenile after Treatment with Plant Extracts of Bidens pilosa

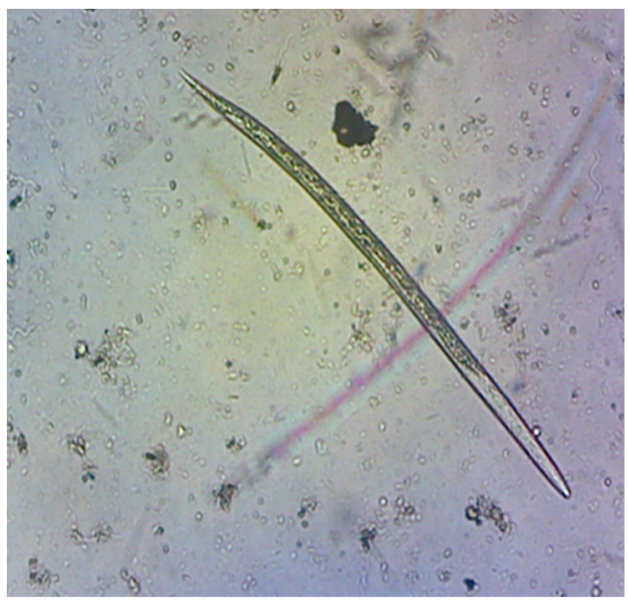

Plate 4: Photomicrograph Of Nematode Juvenile After Treatment with Plant Extracts of commenlina benghalensis

\section{Discussion}

The phytochemical analysis showed that the leaf extracts of Commenlina benghalensis and Bidens pilosa contain some biological active ingredient which include Alkaloid, Flavonoid, Tannin, Saponin, Steroid, Cardiac glycoside and Phlobattam. This agrees with the report of Chitwood (2002) who reported the presence of bioactive compounds such as Alkaloid, Tannin, Saponin, Flavonoid, Steroid among others in some plants. He further said that these substances possess nematicidal properties. This, therefore, explains the nematicidal activities of the leaf extracts in the present study.

The nematicidal activities of the leaf extracts increased with concentration and time of exposure. This agree with the report of Wonang et al. (2006). Who had similar result working with rice straw extract.

The observed mortality in the control treatment may have been as a result of starvation. The finding of this study suggest that the leaves of this plants hold good promise of nematicidal activity and should be investigated in-vivo with a view of utilizing them as organic amendment.

The use of leaves extract of Commenlina benghalensis and Bidens pilosa for organic amendment will have the advantage of decomposing into manure that can serve as source of nutrients to the crop as well. The leaves extract will also serve as a good and cost effective control measure in the treatment of Root-knot nematode. This agree with Wiratno et al (2009) who reported that pesticides from plant origin, known as botanical pesticides is an alternative control strategy, to chemical control which is effective as the synthetic pesticides and safer for use by the farmers, consumers and its eco-friendly. 


\section{Conclusion}

The findings of this study suggests that the different concentration of $C$. benghalensis and B. pilosa leaf extracts holds a good promise of nematode control. The plant extracts are therefore recommended for use as botanical nematicides for the management of root-knot nematodes. This will be of immense benefit to the farmer and his plants being that the leaf extracts will play a dual role of organic amendment and a nematicidal agent.

\section{ACKNOWLEDGEMENTS}

We wish to acknowledge the Chief Technologist of the Department of Plant Science and Biotechnology, Ms Kate Bassey for her assistance in the Lab., also worthy of mention are the tomato and banana farmers in Jos and its surrounding who allowed us took samples from their farms for nematode assay. We are indeed grateful to the Department of Plant Science and Biotechnology, University of Jos for availing us her Laboratory for this study

\section{References}

Adekunle, O. K. (2011). Amendment of soil with African marigold and sunn Hemp for management of Meloidogyne incognita in selected legumes. Crop Protection, 30 (11), 1392-1395.

Agrios, G. (1997). Plant pathology, $4^{\text {th }}$ edition. Academic Press, London, UK, pp. 565-597.

Agrios, G. N. 2005. Plant Pathology $5^{\text {th }}$ edition. Academic Press. New York. 922 pp.

Association of Official Analytical Chemists, A. O. A. C. (2007). Official Methods of Analysis, $18^{\text {th }}$ Edition, Published by Inc.; 2200 Wilson Boulevard: Arlington, Virginia, USA.

Budai, C., Szantone,V. and Nadasy, M. (2005). Harmful parasitic nematodes. Gyakorlati Agro Forum, 16(12): $34-$ 46.

Chitwood, D.J. (2002). Phytochemical based strategies for nematode control. Annual Review of Phytopathology, 40: $221-249$.

Chitwood, D.J. (2003). Research on plant parasitic nematode biology conducted by the

United States, Department of Agriculture- Agricultural Research Service Pest Management Science, 59: 748-753.

Collange, B., Navarrete, M., Peyre, G., Mateille, T., \& Tchamitchian, M. (2011). Root-knot Nematode (Meloidogyne) management in vegetable crop production: The challenge of an agronomic system analysis. Crop Protection, 30 (10), 1251-1262.

Dubreuil, G., Deleury, E., Magliano, M., Jaouannet, M., Abad, P., \& Rosso, M.-N. (2011). Peroxiredoxins from the plant parasitic root-knot nematode, Meloidogyne incognita, are required for successful development within the host. International Journal for Parasitology, 41(3-4), 385-96.

Favery, B., Quentin, M., Jaubert-Possamai, S., \& Abad, P. (2016). Gall-forming root-knot Nematodes hijack key plant cellular functions to induce multinucleate and hypertrophied feeding cells. Journal of Insect Physiology, 84, 60-9.

Gheysen, G., \& Mitchum, M. G. (2011). How nematodes manipulate plant development Pathways for infection. Current Opinion in Plant Biology, 14(4), 415-21.

Hussaini, S. S. (2014). Integrated Pest Management. Elsevier.

Jones, J. T., Haegeman, A., Danchin, E. G. J., Gaur, H. S., Helder, J., Jones, M. G. K., Perry, $\quad$ R. N. (2013). Top 10 plant-parasitic nematodes in molecular plant pathology Molecular Plant Pathology, 14(9), 946-961.

Kayani, M. Z., Mukhtar, T., \& Hussain, M. A. (2012). Evaluation of nematicidal effects of Cannabis sativa L. and Zanthoxylum alatum Roxb, against root-knot Nematodes, Meloidogyne incognita. Crop Protection, 39 , $52-56$.

Khan, A., Fatima, Q., Shaukat, S.S. and Jaffry, A.H. (2004). An eco-friendly Approach for the management of nematode associated with chilli. Pakistan Journal of Scientific and Industrial Research, 47: 135-137.

Khan M. R., Jain R. K., Ghule T. M. and Pal S. (2014). Root-knot nematodes in India comprehensive monograph. All India Coordinated Research Project on Plant Parasitic nematodes with Intergrated approach for their control, Indian Agricultural Research Institute, New Delhi. Pp78.

LaMondia, J. A. and Halbrendt J. M. (2004). Crop rotation and other cultural practices. Pp 909-930 in Chen, Z. X., Chen, S. Y. and Dickson, D. W., eds. Nematology Advances and Perspectives: vol. II Nematode Management and Utilization. Oxfordshire, UK: CAB International.

Luc, M., Bridge, J. and Sikora,R. A. (2005). Plant parasitic nematodes in subtropical and Tropical agriculture. $2^{\text {nd }}$ edition. CAB International. UK. Pp. 1-10.

Manandhar N, S. P, (2000) Plant and people of Nepal, Timber press, Nepal. Pp 167

Nicol, J. M., Turner, S. J., Coyne, D. L., Nijs, L. Den, \& Hockland, S. (2011). Current Nematode Threats to World Agriculture.

Olsen, M. W. (2000). Root-knot Nematode. Agriculture, 1-3.

Perry, R. N., Moens, M., \& Starr, J. L. (2009). Root-Knot Nematodes. CABI Publising, CAB International, Wallingford. pp 22

Sikora, R. A. (1992). Management of the Antagonistic Potential in Agricultural Ecosystems for the Biological 
Control of Plant Parasitic Nematodes. Annual Review of

Phytopathology, 30(1), 245-270.

Singh, R., Kumar, U. and Singh, A. (2015). Nematicidal efficacy of botanicals extracted from Adhatoda vasica and Andrographis affinis against Meloidogyne incognita. I.j.s.n., 6 (2):155-160.

Southey, J. F. (1970). Laboratory Technique for Work with Plant and Soil Nematodes. Tech bill to her Majesty Stationary Office London, pp. 148.

Torr, P., Heritage, S. and Wilson, M.J. (2007). Steinernema kraussei, an indigenous Nematode found in coniferous forests: efficacy and field persistence against Hylobius abietis. Agriculture Forest Entomology, 9: 181- 188.

Webster, T. M., Burton, M. G., Culpepper, A. S., York, A. C. and Prostko, E. P. (2005). Tropical spiderwort (Commenlina benghalensis): A tropical invader invader threatens agroecosystem of the southern United states. Weed technol. 19: 501-508.

Williamson, V.M. and Hussey, R.S. (1996). Nematode pathogenesis and resistance in plants. The Plant Cell, 8: $1735-1745$.

Wiratno, Taniwiryono, D., Van den Berg, H.,Riksen, J. A. G., Rietjens, I. M. C. M., Djiwanti, S. R., Murk, A. J. (2009). Nematicidal Activity of Plant Extracts against the Root- Knot Nematode, Meloidogyne incognita. The Open Natural Products Journal, 2(OCTOBER), 77-85

Wonang, D. L., Okechalu, B. O. and Agaba, O. A. (2006). In-vitro studies on the Nematicidal Properties of Rice Straw Extract. Nigeria Journal of Botany 19(1): 117-12 